\title{
EFEKTIVITAS JAHE TERHADAP PENURUNAN HIPEREMESIS GRAVIDARUM PADA IBU HAMIL TRIMESTER I
}

\author{
Rr. Catur Leny $W^{1}$, Ida Safitri ${ }^{2}$ \\ 12 Program Studi Kebidanan Program Sarjana Bidan Fakultas Kedokteran \\ Universitas Islam Sultan Agung \\ Email: ${ }^{1}$ caturleny@unissula.ac.id,2idasafitri0705@gmail.com
}

\begin{abstract}
Introduction: nausea and vomiting are often experienced by pregnant women, especially at a young gestational age. The occurrence of nausea and vomiting at a young gestational age is due to hormonal changes that occur in every pregnant woman. According to data from the World Health Organization, $12.5 \%$ of pregnant women experience Hyperemesis Gravidarum and usually attacks at a young age. There are several therapies that can be used to reduce nausea and vomiting in pregnant women, one of which is therapy with ginger drinks. Methods: International and domestic literature were traced through several media using keywords as the PICO formula. The articles selected were 8, 5 foreign and 3 domestic, each of which had its own results. Results: There are differences in results that indicate the level of effectiveness of ginger in the incidence of hyperemesis gravidarum in pregnant women. Discussion: there are many pharmacological ways that can be given for the occurrence of hyperemesis gravidarum, but there are also non-pharmacological or herbal methods that we can provide for the occurrence of hyperemesis gravidarum, one of which is ginger therapy. For ginger, it can be processed in various kinds, some are in powder form and some are in the form of rhizome. Conclusion: After analyzing ginger, it can be concluded that ginger is effective in reducing hyperemesis gravidarum.
\end{abstract}

Key words: Hyperemesis Gravidarum; pregnant women; Ginger

\begin{abstract}
ABSTRAK
Pendahuluan: mual muntah sering kali dialami oleh ibu hamil terutama di usia kehamilan muda. Terjadinya mual muntah di usia kehamilan muda disebabkan perubahan hormonal yang terjadi di setiap ibu hamil. Menurut data World Health Organization terdapat $12,5 \%$ ibu hamil yang mengalami Hiperemesis Gravidarum dan biasanya menyerang diusia muda. Ada beberapa terapi yang bisa digunakan untuk mengurangi mual muntah pada ibu hamil, salah satunya adalah terapi dengan minuman jahe. Metode : Literatur mancanegara dan domestik ditelusuri melalui beberapa media menggunakan kata kunci sebagaimana rumus PICO. Artikel yang dipilih sebanyak 8, 5 mancanegara dan 3 domestik yang masing masing memiliki hasil tersendiri. Hasil : adanya perbedaan hasil yang menunjukan tingkat efektivitas jahe pada kejadian hiperemesis gravidarum pada ibu hamil. Pembahasan : banyak cara farmakologi yang bisa diberikan untuk kejadian hiperemesis gravidarum ini, namun ada juga cara nonfarmakologi atau cara herbal yang bisa kita berikan untuk kejadian hiperemesis gravidarum tersebut salah satunya yaitu terapi jahe. Untuk jahe ini bisa diolah dengan berbagai macam, ada yang berbentuk bubuk dan ada pula yang berbentuk rimpangnya. Kesimpulan : setelah dilakukan analisa terhadap pemberian jahe maka dapat disimpulkan bahwa jahe memiliki efektivitas untuk mengurangi hiperemesis gravidarum.
\end{abstract}

Kata kunci : Hiperemesis Gravidarum; Ibu hamil; Jahe.

\section{PENDAHULUAN}

Kehamilan merupakan suatu keadaan yang didambakan oleh pasangan suami istri baik yang baru menikah maupun yang sudah lama menikah. Kehamilan merupakan proses yang alamiah dan juga hal yang normal terjadi pada seseorang yang sudah melakukan hubungan intim lalu dilanjut 
dengan proses ovulasi dan akhirnya terjadi implementasi pada dinding rahim yang berlangsung sampai 40 minggu (normalnya) ${ }^{(1)}$

Pada kehamilan biasanya akan terjadi banyak perubahan diantaranya perubahan hormonal yang dapat berakibat perubahan anatomi pada ibu hamil. Salah satu perubahan hormonak yang akan dialami ibu hamil yaitu ketidakseimbangan kinerja hormon progesteron, estrogen dan juga adanya hormon hCG (Human Chorionic Gonadotropin). Dan salah satu efek yang diakibatkan dari hormon hCG adalah mual muntah (emesis gravidarum) yang bisa juga berujung pada kejadian mual muntah berlebih (hiperemesis gravidarum). ${ }^{(2)}$

Kejadian mual muntah atau pun mual muntah berlebih biasanya menyerang ibu hamil dengan usia kehamilan muda atau kita sebut Trimester 1. Menurut penelitian Amin dkk, (2015), Hiperemesis gravidarum adalah mual dan muntah yang lebih dari 10 kali dalam 24 jam atau setiap saat pada wanita hamil.

Menurut World Health Organization (WHO, 2010) angka kejadian emesis gravidarum terjadi sebanyak $14 \%$ dari semua wanita hamil. Sedangkan menurut Kemenkes (2018), wanita hamil di Indonesia berjumlah 5.291.143, dari jumlah ibu hamil yang mengalami keadaan hiperemesis gravidarum mencapai 14,8\%. Dahulu hiperemesis gravidarum menjadi penyebab kematian maternal yang signifikan, namun sekarang hiperemesis tidak lagi menjadi penyebab utama mortalitas ibu, tetapi hiperemesis masih menjadi penyebab morbiditas ibu yang signifikan.

Kementrian Kesehatan Republik Indonesia menjelaskan bahwa lebih dari $80 \%$ ibu hamil di Indonesia mengalami mual dan muntah yang berlebihan, yang dapat menyebabkan ibu hamil menghindari jenis makanan tertentu dan akan dapat menyebabkan risiko bagi dirinya maupun janin yang sedang dikandungnya.

Untuk kejadian hiperemesis gravidarum banyak sekali terapi yang bisa dilakukan, salah satunya ada pemberian jahe sebagai intervensi nonfarmakologi yang dapat mengurangi kejadian mual muntah berlebih. Namun, ada beberapa penelitian yang mengatakan bahwa jahe kurang efektif untuk mengurangi hyperemesis gravidarum.

Jahe merupakan rimpang yang memeiliki fungsi sebagai antiemetik (anti muntah), sebagai stimulan aromatik yang kuat sehingga dapat mengendalikan muntah melalui peningkatan gerakan peristaltik usus. Rimpang jahe terdiri dari 6 senyawa yaitu minyak atsiri zingiberena (zingirona), zingiberol, bisabilena, kurkumen, gingerol dan flandrena yang sudah terbukti sebagai antiemetik. $^{(2)}$

Menurut TIM Lentera dalam bukunya yang berjudul "Khasiat dan manfaat Jahe Merah di Rimpang Ajaib" disebutkan banyak sekali kandungan yang terdapat pada jahe, salah satunya minyak atsiri. Dalam minyak atsiri terdapat banyak unsur unsur n-nonylaldehyde, d-camphene, cineol, geranion, acetates, dll. Sedangkan untuk manfaat yang terkadung pada jahe bisa sebagai penguat lampung, masuk angin, muntah-muntah, radang tenggorokan, nyeri oto, sakit demam, dll. ${ }^{(3)}$

\section{METODE}

Peneliti melakukan pencarian artikel melalui berbagai media elektronik atau pun database diantaranya google scholar. Untuk jurnal dosmetik yang berkriteria sinta 3,5, dan jurnal mancanegara yaitu Pubmed, BMC, PMC yang akhirnya mendapat jurnal terbitan BioMed Central, ElSevier, SAGE Journals, NIH, MDPI. Dilakukannya artikel ini bertujuan untuk mengupas khasiat jahe untuk masalah mual muntah berlebih. Kata kunci yang digunakan dalam pencarian literatur yaitu "ginger for hyperemesis gravidarum”. Kriteria inklusi nya yaitu manfaat jahe untuk hiperemesis gravidarum Dan setelah dilakukan pencarian dan disesuaikan dengan kriteria inklusi didapatkan 5 jurnal mancanegara dan 3 jurnal domestik yang bertemakan "jahe untuk hyperemesis gravidarum".

\section{HASIL DAN PEMBAHASAN}

Artikel Penelitian yang berjudul "Perbandingan Efektivitas Pemberian Rebusan Jahe Merah Dan Daun Mint Dengan Jeruk Nipis Dan Madu Terhadap Mual Muntah Pada Ibu Hamil Trimester I Di Puskesmas Waepana, Ngada, Ntt". menggunakan metode quasi experiment dengan dengan pendekatan pretest-posttest with design two eksperimen, pengambilan sampel purposive sampling dengan rumus Lameshow 1990. Jumlah sampel 22. responden (11 kontrol dan 11 intervensi). Kelompok perlakuan diberikan ekstrak jahe merah dan daun mint. Kelompok kontrol diberikan jeruk nipis dan madu. Uji statistik menggunakan uji parametrik yaitu Wilcoxon dan Mann Whitney sedangkan uji normalitas menggunakan uji Shapiro-Wilk. Hasil penelitian ini menunjukkan bahwa terjadi perbedaan antara kelompok yang diberi jahe merah dan daun mint 
yaitu $(p=0,004)$. Kesimpulan adanya perbedaan yang signifikan kelompok setelah diberi terapi jahe merah dan daun mint. ${ }^{(2)}$

Artikel Penelitian yang diteliti oleh (Rufaridah, et all, 2019) yang berjudul "Pengaruh Seduhan Zingiber Offcinale (Jahe) Terhadap Penurunan Emesis Gravidarum". menggunakan metode pra experiment dengan dengan pendekatan pretest-posttest with one group, pengambilan sampel purposive sampling, Jumlah sampel 12 dengan kriteria inklusi bersedia menjadi responden, berada ditempat saat penelitian, ibu hamil dengan mual muntah $\leq 10 \mathrm{x}$ sehari, trimester 1 dan kriteria eksklusi mengkonsumsi obat anti mual muntah, dan menderita penyakit lain. Untuk data numerik digunakan mean atau nilai rata-rata dan kategorik digunakan chi-square.Penelitian ini menggunakan uji normalitas Shapiro wilk untuk mengetahui data terdistribusi normal atau tidak. Lalu dilakukan uji paired sample T-Test dimana pengujani dilakukan dengan komputerisasi Hasil penelitian ini menunjukkan bahwa terjadi perbedaan setelah diberikan jahe yaitu $(\mathrm{p}=0,000)$. Kesimpulan adanya perbedaan frekuensi yang signifikan setelah diberi terapi seduhan jahe. ${ }^{(4)}$

Artikel Penelitian yang berjudul "Efektifitas Pemberian Jahe Hangat Dalam Mengurangi Frekuensi Mual Muntah Pada Ibu Hamil Trimester I". menggunakan metode praEksperimen yang bersifat one grup pretest-posttest. Jumlah sampel 34 orang. Penelitian ini menggunakan Paired Sampel t-test. Hasil penelitian ini menunjukkan bahwa terjadi perbedaan setelah diberikan jahe hangat yaitu $(\mathrm{p}=0,000)$. Kesimpulan adanya perbedaan frekuensi yang signifikan setelah diberi terapi permen jahe. ${ }^{(5)}$

Artikel Penelitian yang berjudul "How Safe Is Ginger Rhizome for Decreasing Nausea and Vomiting in Women during Early Pregnancy?". menggunakan metode Review artikel dengan uji acak dan studi vivo untuk mendeteksi terhadap toksisitas. Kesimpulan dari 15 studi dan 3 studi klinis yag meneliti tentang konsumsi jahe bagi ibu hamil ialah adanya penurunan mual muntah yang signifikan pada ibu hamil. ${ }^{(6)}$

Artikel Penelitian yang berjudul "Hyperemesis Gravidarum". Jurnal ini menggunakan metode A Review of Recent Literature, sehingga ia hanya mengindentifikasi mual muntah serta obat obatannya saja. Pada jurnal ini dijelaskan bahwa akar jahe (Zingiber Officinale Roscoe) dapat terbukti sangat efektif untuk mengurangi mual muntah pada ibu hamil. ${ }^{(7)}$
Artikel Penelitian yang berjudul "Ginger treatment of hyperemesis gravidarum". menggunakan design cross-over trial dengan sistem acak dan 2 grup, Jumlah sampel 30. Penelitian ini menggunakan uji Mann-Whitney test. Hasil penelitian ini menunjukkan bahwa terjadi perbedaan setelah diberikan jahe yaitu $(\mathrm{p}=0,003)$. Kesimpulan adanya perbedaan frekuensi yang signifikan setelah diberi terapi jahe ${ }^{(8)}$

Artikel Penelitian yang berjudul "Ginger (Zingiber officinale Roscoe) and the Gingerols Inhibit the Growth of Cag A+ Strains of Helicobacter pylori". menggunakan eksperimen murni yaitu pada hewan yang memiliki kriteria yang sudah ditentukan peneliti. Hasil penelitian ini menunjukkan bahwa Ekstrak metanol kasar rimpang jahe menghambat pertumbuhan 14 klinis isolat, 4 strain CagA +, serta strain H. pylori ATCC43504 dengan MIC dari 25,0 $\mu \mathrm{g} / \mathrm{ml}$ (kisaran 6,25 hingga 50,0 $\mu \mathrm{g} / \mathrm{ml}){ }^{(9)}$

Artikel Penelitian yang berjudul "Which potential harms and benefits of using ginger in the management of nausea and vomiting of pregnancy should be addressed? a consensual study among pregnant women and gynecologists". menggunakan design observasi. Artikel ini melakukan uji pre-post dengan lembar checklist, Jumlah sampel 50. Kesimpulannya pana penelitian ini perlu dilakuka uji kembali untuk efektivitas jahe terhadap mual dan muntah pada ibu hamil. ${ }^{(10)}$

Setelah dilakukan analisa terhadap 8 jurnal yang sudah dipaparkan diatas yaitu adanya hubungan antara pemberian jahe dengan kejadian mual muntah berlebih atau Hyperemesis Gravidarum pada kehamilan pertama. Namun ada juga yang menyarankan untuk diuji ulang dikarenakan design yang digunakan yaitu lembar cheklist, sehingga beberapa responden ada yang tidak mengumpulkan dan itu mempengaruhi data yang dihasilkan.

Hasil penelitian rata-rata ibu hamil yang mengalami hiperemesis gravidarum sebelum diberikan terapi jahe mengalami tingkatan mual muntah yang cukup parah, berbeda dengan ibu hamil yang sudah diberikan terapi jahe dalam bentuk minuman, permen, maupun yang lain mengalami perubahan yang signifikan.

Indonesia pun sebagai penghasil rempahrempah yang terbilang cukup tinggi memudahkan seluruh responden mendapatkan jahe baik itu untuk obat maupun untuk hal yang lain. 
Jahe memiliki efektivitas untuk mengurangi kejadian emesis gravidarum pada ibu hamil dengan trimester pertama, sehingga setelah diberikan jahe terdapat penurunan mual muntah yang terjadi pada ibu hamil. ${ }^{(2)}$

\section{SIMPULAN DAN SARAN}

\section{Simpulan}

Berdasarkan analisa yang telah dilakukan pada 8 jurnal dan artikel dapat disimpulkan bahwa jahe memiliki khasiat untuk mengurangi mual muntah pada ibu hamil.

\section{Saran}

Saran yang dapat diberikan oleh penulis untuk literature review selanjutnya adalah melakukan uji coba dengan artikel yang lebih relevan dan lebih terstandar tingkat tinggi serta tetap mengkaji khasiat jahe dari sudut pandang Islami. Selain untuk kemajuan ilmu pendidikan, ini juga bisa sebagai bukti kebesaran Allah SWT yang telah menciptakan jahe dan dituangkan dalam Al-Quran. Dan untuk kita sebagai pelajar atau bahkan ibu hamil yang sedang mengalami mual muntah disarankan untuk menyoba jahe terlebih dahulu sebelum akhirnya mengkonsumsi obat-obatan.

\section{DAFTAR PUSTAKA}

1. Prawirohardjo S. ILMU KEBIDANAN. Empat. Saifuddin AB, editor. jakarta: Bina Pustaka; 2016. 1-981 p.

2. Soa UOM, Amelia R, Octaviani DA. Perbandingan Efektivitas Pemberian Rebusan Jahe Merah Dan Daun Mint Dengan Jeruk Nipis Dan Madu Terhadap Mual Muntah Pada Ibu Hamil Trimester I Di Puskesmas Waepana, Ngada, Ntt. J Kebidanan. 2018;8(2):157.

3. LENTERA T. Khasiat dan manfaat Jahe Merah di Rimpang Ajaib. Jakarta Selatan: Agro Media Pustaka; 2002.

4. Wati H. Pengaruh Jahe (Zingiber Officinale) Hangat Dalam Mengurangi Emesis Gravidarum Di Wilayah Kerja Puskesmas Harapan Raya Pekanbaru. AlInsyirah Midwifery J Ilmu Kebidanan (Journal Midwifery Sci. 2020;9(1):1-7.

5. Rusman ADP, Andiani D, Fakultas Ilmu Kesehatan U. Prosiding Seminar Nasional IKAKESMADA "Peran Tenaga Kesehatan dalam Pelaksanaan SDGs" EFEKTIFITAS PEMBERIAN JAHE HANGAT DALAM MENGURANGI FREKUENSI MUAL MUNTAH PADA IBU HAMIL TRIMESTER I. Pros Semin Nas. 2017;978-9.

6. Stanisiere J, Mousset PY, Lafay S. How safe is ginger rhizome for decreasing nausea and vomiting in women during early pregnancy? Foods. 2018;7(4).

7. London V, Grube S, Sherer DM, Abulafia O. Hyperemesis gravidarum: A review of recent literature. Pharmacology. 2017;100(3-4):161-71.

8. Fischer-Rasmussen W, Kjær SK, Dahl C, Asping U. Ginger treatment of hyperemesis gravidarum. Eur J Obstet Gynecol Reprod Biol. 1991;38(1):19-24.

9. Mahady GB, Pendland SL, Yun GS, Lu ZZ, Stoia A. Ginger (Zingiber officinale Roscoe) and the Gingerols Inhibit the Growth of Cag A+ Strains of Helicobacter pylori. Anticancer Res. 2003;23(5 A):3699-702.

10. Shawahna R, Taha A. Which potential harms and benefits of using ginger in the management of nausea and vomiting of pregnancy should be addressed? A consensual study among pregnant women and gynecologists. BMC Complement Altern Med. 2017;17(1):1-12. 